\title{
Comparative Analysis of 20-MW Solar Thermal and PV Power Plant in Rongkop, Indonesia Using LCOE Simulation Method
}

\author{
Rizky Januar
}

\begin{abstract}
The high average solar radiation in Indonesia makes solar power plant an option to improve renewable energy-based electricity generation in the country. Currently in Indonesia, the photovoltaic (PV) plant has been more widely implemented, and several extensive researches on solar thermal plant have been carried out. In this paper, a comparative study on the 20-MW on-grid solar thermal and photovoltaic (PV) power plant is committed to measure the cost competitiveness of the technologies in Rongkop district, Indonesia; which is recently considered as the center for solar power plant in Indonesia. The simulation follows two installed energy capacity scenarios by the International Energy Agency and is committed up to year 2030, in accordance with the target year of United Nations' Sustainable Development Goals.

By using System Advisor Model it is shown that a 20-MW solar thermal power plant equipped with 6-hour storage is able to produce slightly higher annual energy output than the solar PV plant design of similar capacity. However, the levelized cost of electricity (LCOE) values of both solar thermal plants with no storage and 6-hour storage significantly exceed the LCOE of PV plant throughout the years of simulation. This implies that in Rongkop, Indonesia the PV plant is a more economically competitive solar power plant technology to be implemented until 2030, compared to the solar thermal plant.
\end{abstract}

Index Terms-Energy economics, solar thermal, photovoltaic, Levelized cost of electricity, Rongkop.

\section{INTRODUCTION}

Aspiring to achieve growth in various development sectors requires Indonesia to consider its energy supply and demand in a long term. The National Energy Council of Indonesia projects the increase of overall energy demand up to 277 -298 million TOE (tonne of oil equivalent) until year 2025, with annual rise of 4.9-6.1\%. Between 2025 and 2050, the demand will increase up to 893 million TOE, with annual growth of 4.5-4.8\%. According to the similar scenario, mostly due to the high projection of electrification ratio and both the projected economic and technological growth, the fraction of electricity demand to the overall energy demand grows $6.5 \%$ annually until 2050 [1].

As the global carbon emission increases, reaching around 35 billion tonnes of $\mathrm{CO} 2$ in 2015 [2], the need of exploring clean and renewable energy is utterly strong. The recent United Nations' Sustainable Development Goals (SDGs)

Manuscript received October 9, 2016; revised December 15, 2016

Rizky Januar is with the Faculty of Technology, Policy and Management, Delft University of Technology, Netherlands (e-mail: rizkyjanuar@student.tudelft.nl). platform states that one of its main targets is to increase the share of renewable energy substantially by 2030 [3]. One of the renewable energy options considered is solar power technology, and in this context Indonesia has a geographic potential; in average the country receives sun radiation of 4.8 $\mathrm{kWh} / \mathrm{m} 2$.day [4]. Despite the given potential, however, the economic competitiveness of solar energy option is not yet comparable to the fossil, conventional energy. To improve renewable energy production, Indonesia has implemented several policies, including: 1) Feed-in Tariff scheme for renewable energy-based electricity generation [4], for solar photovoltaic energy it is recently shown in the Ministerial Decree 19/2016 [5]; 2) Oil subsidy gradual removal for transportation sector; and 3) National Energy Policy which targets minimum $23 \%$ of renewable energy production in 2025 [4], [5]. By implementing the National Energy Policy it is expected that renewable energy demand will grow $6.3 \%$ annually, reaching 24 million TOE in 2025 and 69 million TOE in 2050 [1].

In order to further support the renewable energy provision, the Special Region of Yogyakarta province in Indonesia has officially allocated its 270-hectare land in Rongkop district to be the center for solar power plant development in the region [6]. This policy has given way to independent power producers (IPPs) to develop solar power plant in the area [6], [7] (see Fig. 1).

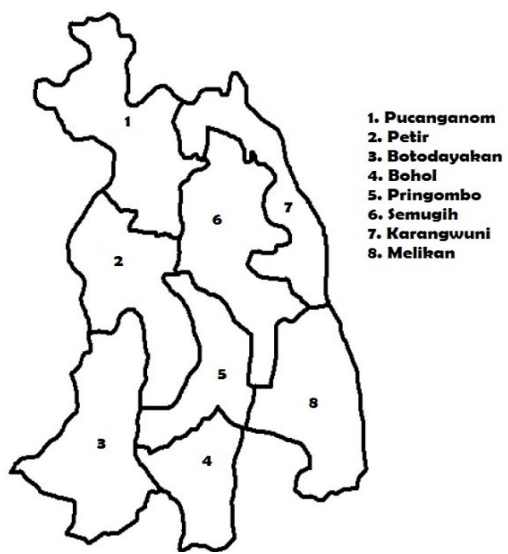

Fig. 1. Map of Rongkop district, with its 8 sub-districts [8].

While around 48-MW capacity of PV power plants have already been implemented in Indonesia until 2014 [1], researches on solar thermal technology have been conducted in Indonesia in recent years [9]-[11]; some emphasizing the suitability of Indonesia to implement the solar thermal technology [11]. 
This paper focuses on committing comparative assessment between two different kinds of solar power plant: photovoltaic and solar thermal. It would give one of the first economic insights on solar thermal and photovoltaic power plant feasibility of implementation until 2030, the target year of SDGs, in Rongkop for the concerned policymakers and investors. By projecting the economic value of the plant types it is then expected to inform policy in ensuring sustainable solar energy development in Rongkop area, given that it is recently established as the center for solar power plant in Yogyakarta province and also in Indonesia.

\section{SOLAR ENERGY TECHNOLOGY}

In terms of generating electrical energy from the sun, photovoltaic (PV) is a technology that has strong potential of future growth [12]. The working principle of solar cell technology can be described in a form of $\mathrm{P}-\mathrm{N}$ junction concept. If a solar cell is exposed to the sunlight, the energy from the light particle will be absorbed in an area called depletion region, resulting in holes and free electrons which are pushed into the P-type and N-type material, respectively. A conductor set between the N-type and P-type material will bridge the electron flow from the N-type to the P-type material. Ultimately, electrical power as a product of the electron flow (i.e. electrical current) and the voltage derived from the electric field in the depletion region is produced. [13].

Regarding the commercial and technological maturity of solar cells, the crystalline silicon has considerably the biggest advantage in dominating the solar energy markets, while silicon material itself is also highly abundant in the earth [12], [14], [15]. Depending on the silicon manufacturing process, crystalline silicon is mainly classified into three kinds: monocrystalline (mono-c-Si), polycrystalline (poly-c-Si), and EFG ribbon silicon (EFG c-Si) [14].

Ultimately, a photovoltaic system should consist of the solar cells which are formed into modules, as well as additional components such as inverter, wiring equipment, transformer, etc. [14]. In terms of on-grid application, it has been suggested that energy storage e.g. in form of a battery is not yet economically feasible; also, PV storage is more commonly used in the off-grid applications [16], [17].

Aside of the PV technology, in terms of solar power technology, solar thermal power plant has also become a growing option [11], [18], [19]. The solar thermal technology utilizes the sun radiation to heat a fluid, which then produces steam; the steam will later be used to run the turbine in order to create electricity power. In terms of collecting and concentrating the sun radiation, the solar thermal consists of several technologies e.g. parabolic trough, linear fresnel reflector, parabolic dish, and central receiver (solar tower) [15]. Among others, parabolic trough thermal plant has the largest commercial utilization due to its mature technological development [9], [16], [20], [21]. Parabolic trough solar collector technology has also been developed in Gunungkidul regency, Yogyakarta [10].

On parabolic trough plant, one-axis tracking concept is used for the solar collector to track the sun. Then, the sun irradiance is focused onto a linear receiver. This way, parabolic trough distinguishes itself from parabolic dish and solar tower technology, where the two-axis tracking concept is mainly used and the irradiance focused onto one-point receiver [15], [21].

To deal with the issues of output variations and dispatchability, the solar thermal plant can be equipped with thermal storage. When there is any excess heat energy available, it will be transferred into a storage material; so when required, the stored heat will then be released for the plant to produce electricity. Using the storage technology, the plant system cost can be considerably more expensive compared to the plant with no storage equipment [15]. The size of storage may have a relation to the number of solar multiple, which is the ratio of solar field equipped in the plant to the amount of solar field used to produce rated power capacity at the optimal condition of the plant [21]. Solar field ratio is an important variable, since undersizing will result in low capacity factor while oversizing may result in wasted energy if the plant is not equipped with storage [22]. Storage is usually measured in hours, i.e. the number of hours for which the plant can run at its rated power from the storage only [15].

In this research, due to the planned condition in Rongkop, power capacity of $20 \mathrm{MW}$ is considered for both PV plant and solar thermal plant [7].

\section{A. Solar Thermal}

For solar thermal PV plant, in this research parabolic trough plant using synthetic oil as the heat transfer fluid is used due to its commercial availability and also its maturity in technology [9], [16]. In this simulation, two main types of solar thermal plant are used: the solar thermal plant with no storage, and the solar thermal plant equipped with 6-hour storage; and the specifications used follow the case given by Turchi [23], whose concept is similar to the ones of Andasol-1, the solar thermal power plant implemented in Spain [23], [24]. Therefore, other than the ones provided in Table I, the assumed plant design will mainly follow the specifications of Andasol-1.

TABLE I: STATISTICS OF RONGKOP DISTRICT [22]

\begin{tabular}{|c|c|}
\hline \multicolumn{2}{|l|}{ Rongkop District } \\
\hline Regency & Gunung Kidul \\
\hline Province & $\begin{array}{lll}\text { Special } & \text { Province } & \text { of } \\
\text { Yogyakarta } & & \end{array}$ \\
\hline Country & Indonesia \\
\hline Total Area & $8346 \mathrm{Ha}$ \\
\hline Number of Villages & 8 \\
\hline Number of Population & 32448 \\
\hline Schools & 64 \\
\hline Approximate Coordinates & $-8.096,110.748$ \\
\hline
\end{tabular}

TABLE II: SPeCifications of Simulated Solar Thermal Plant [23]

\begin{tabular}{|l|l|l|}
\hline Type & No-storage & 6-hour storage \\
\hline Heat transfer fluid & Synthetic oil \\
\hline Solar collector & Solargenix SGX-1 \\
\hline Solar field temperature & $391^{\circ} \mathrm{C}$ & \\
\hline Solar multiple & 1.3 & 2 \\
\hline Thermal Storage Hours & 0 hours & 6 hours \\
\hline System availability & $94 \%$ & \\
\hline Turbine efficiency & 0.377 & \\
\hline Collector reflectance & 0.935
\end{tabular}




\section{B. $P V$}

The assumed solar PV plant design in this paper is shown in Table III [25]. The whole PV plant design is then configured with System Advisor Model, a software developed by the National Renewable Energy Laboratory (NREL).

TABLE III: SPECIFICATIONS OF PV PLANT

\begin{tabular}{|l|l|}
\hline \multicolumn{2}{|l|}{$\begin{array}{l}\text { Module: } \\
\text { SunPower SPR-300E-WHT-D }\end{array}$} \\
\hline Material & monocrystalline \\
\hline Nominal efficiency & $18.4122 \%$ \\
\hline Maximum Power (Pmp) & $300.303 \mathrm{Wdc}$ \\
\hline $\begin{array}{l}\text { Inverter: } \\
\text { Power One : PVI-CENTRAL-50-US (480) 480V Inverter }\end{array}$ \\
\hline Maximum AC Output Power & $50000 \mathrm{Wac}$ \\
\hline Manufacturer Efficiency & $95.105 \%$ \\
\hline DC-to-AC ratio & 1.1 \\
\hline
\end{tabular}

According to the simulated configuration, total of 66592 modules and 364 inverters are used. Losses for the PV design are divided into several terms: irradiance losses, DC losses, $\mathrm{AC}$ losses, and loss of availability; whose details are given in Table IV. The assumed DC losses follow the specifications of string inverters in SAM, and the constant loss follows the similar value of the solar thermal power plant model given above.

TABLE IV: LOSSES OF PV SYSTEM

\begin{tabular}{|c|c|c|}
\hline \multicolumn{3}{|l|}{ Irradiance losses } \\
\hline Average soiling loss & 5 & $\%$ \\
\hline \multicolumn{3}{|l|}{ DC losses } \\
\hline Module and mismatch & 2 & $\%$ \\
\hline Diode and connections & 0.5 & $\%$ \\
\hline DC wiring & 2 & $\%$ \\
\hline \multicolumn{3}{|l|}{ AC losses } \\
\hline AC wiring & 1 & $\%$ \\
\hline Step-up transformer & $1[33]$ & $\%$ \\
\hline \multicolumn{3}{|l|}{ Availability } \\
\hline Constant loss & 6 & $\%$ \\
\hline
\end{tabular}

\section{LCOE MODEL AND SCENARIO}

In terms of comparing economic feasibility of various electrical energy generation technologies, the levelized cost of electricity method can be utilized [14], [26], [27], [28]. Levelized cost of electricity (LCOE) is the price of a unit of energy generated by a certain technology at a time when the present value of the revenues equals the present value of the total costs during the whole lifetime of the system [29].

In order to estimate the current as well as the future economic competitiveness of both solar thermal and PV plant technologies in Rongkop to fulfill the Sustainable Development Goals platform, the LCOE of both technologies is simulated on annual basis until year 2030. The simulation follows the lines of two cumulative power capacity projection scenarios for both electricity generation technologies by the International Energy Agency (IEA). Regarding solar energy technology, the scenarios are distinguished by different projected penetration in the energy market. The first is called the Blue Map scenario [18]. In terms of reducing global emission as stated earlier, it is an energy scenario by which carbon emission can be reduced up to $48 \mathrm{Gt}$ by year 2050. The second one is called the Road Map scenario [12], an energy scenario by which emission is expected to decrease up to 100 $\mathrm{Gt}$ in 2050 . Both scenarios have also been utilized by recent LCOE researches of solar plants [16], [27].

The mathematical equation for calculating LCOE of a plant over the years [27] is given in Equation (1).

$$
\begin{aligned}
& \mathrm{LCOE}_{(\mathrm{t})}= \\
& \frac{\mathrm{C}(0)\left(\frac{Q(t)}{Q(t(0))}\right)^{\frac{\log (1-L R)}{\log (2)}}+L+\sum_{n=1}^{N} \frac{(O M+I) x C(0)\left(\frac{Q(t)}{Q(t(0))}\right)}{(1+r)^{n}} \frac{\log (1-L R)}{\log (2)}}{\sum_{n=1}^{N} \frac{S \times T F \times P F \times(1-d)^{n}}{(1+r)^{n}}}
\end{aligned}
$$

where the description of each variable is given below:

- $\mathrm{LCOE}_{(\mathrm{t})}$ : Levelized cost of electricity given that the project is installed in year $\mathrm{t}(\mathrm{cUS} \$ / \mathrm{kWh})$

- $C_{(0)}$ : the PV system cost at the initial year of simulation (US\$/W).

- $Q_{t(0)}$ : global cumulative installed capacity of respectively PV and solar thermal plant at reference year $(\mathrm{GW})$.

- $Q_{(t)}$ : global cumulative installed capacity at a particular year of simulation $(\mathrm{GW})$

- LR: learning rate (\%). Defined as expected improvement of PV and solar thermal technology based on the accumulation of related experiences [30].

- L: land cost (US\$/W). Since the all-round 270-hectare area in Rongkop is specifically prepared by the local government for solar plant development including feasibility study and project implementation [6], in this simulation in Rongkop the land cost for both technologies is assumed zero.

- $N$ : expected lifetime of the plant (year).

- OM: operation and maintenance cost (\%); given as a fraction to the plant system cost at the year of installation.

- I: insurance cost (\%); also given as a fraction to the PV capital cost

- $S$ : solar resource $\left(\mathrm{kWh} / \mathrm{m}^{2} /\right.$ day); the value is specific for a particular site. In this paper, the values are derived from simulation using Meteonorm software. It is of particular note that PV and thermal plant utilize different solar resources [27]. PV plant may make use of the global horizontal irradiance (GHI), which consists of direct and diffuse radiation; while the solar thermal plant can only use the direct normal irradiance (DNI).

- $r$ : discount rate (\%). Using the discount rate variable, the discounted cash flow method is performed to get the present values of cost and revenue in regard to the realization of a particular technology [31].

- $T F$ :tracking factor (dimensionless); adjustment factor of the solar resource to usable solar energy

- $P F$ : performance factor $\left(\mathrm{m}^{2} / \mathrm{kW}\right)$; the rate of conversion from the solar resource, after taking tracking factor into account, into electrical power. The value is obtained by taking annual energy output, power capacity, and solar resource into account [16].

- $d$ : degradation rate $(\%)$; annual output decrease due to system degradation.

And the cumulative installed capacity at particular year, 
$Q(t)$, can be derived from Equation (2) [27], [32]:

$$
\frac{e^{r(t-t(0))}}{\frac{1}{Q(t(0))}-\frac{1}{Q(2059)}+\frac{e^{r(t-t(0)}}{Q(2050)}}
$$

where the brief description of each variable is given below:

- $r$ : growth parameter (dimensionless)

- $t$ : particular year of simulation

- $t_{(0)}$ : the reference year of simulation

- $Q_{t(0)}$ : global cumulative installed capacity at the reference year $(\mathrm{GW})$

- $Q_{(2050)}$ : global cumulative installed capacity in 2050 , the end year of Blue Map and Road Map scenarios (GW)

The $Q(t)$ formula above applies for all but the solar thermal plant simulation in Road Map scenario, which utilizes second-grade polynomial formula [16], [27]; given in equation (3):

$$
0.459(t-t(0))^{2}+9.073(t-t(0))+Q(0)
$$

The details of each value of the variables are given in Table V.

\begin{tabular}{|c|c|c|c|c|}
\hline \multirow{2}{*}{\multicolumn{2}{|c|}{ Variable }} & \multirow{2}{*}{ PV plant } & \multicolumn{2}{|c|}{ Thermal plant } \\
\hline & & & No-storage & 6-hour storage \\
\hline \multicolumn{2}{|l|}{$\mathrm{C}_{(0)}$} & $4.43[25]$ & $4.95[15]$ & $8.604[15]$ \\
\hline \multicolumn{2}{|l|}{$\mathrm{Q}_{\mathrm{t}(0)}$} & $191[16]$ & \multicolumn{2}{|l|}{$3.93[16]$} \\
\hline \multirow{2}{*}{$\mathrm{Q}(2050)$} & Blue Map & $1150[18]$ & \multicolumn{2}{|l|}{$630[18]$} \\
\hline & Road Map & 3155 [12] & \multicolumn{2}{|c|}{ 2nd grade polynomial } \\
\hline \multicolumn{2}{|l|}{ LR } & $18[16,27]$ & \multicolumn{2}{|c|}{$10[16,27]$} \\
\hline \multicolumn{2}{|l|}{$\mathrm{L}$} & \multicolumn{3}{|l|}{0} \\
\hline \multicolumn{2}{|l|}{$t_{(0)}$} & \multicolumn{3}{|l|}{2014} \\
\hline \multicolumn{2}{|l|}{$\mathrm{N}$} & $25[16,27]$ & \multicolumn{2}{|l|}{$30[16,27]$} \\
\hline \multicolumn{2}{|l|}{$\mathrm{OM}$} & $1.5[16,27]$ & \multicolumn{2}{|l|}{$2[16,27]$} \\
\hline \multicolumn{2}{|l|}{ I } & $0.25[16,27]$ & \multicolumn{2}{|l|}{$0.5[16,27]$} \\
\hline \multirow{2}{*}{$\mathrm{S}$} & GHI & \multicolumn{3}{|l|}{4.64} \\
\hline & DNI & \multicolumn{3}{|l|}{3.25} \\
\hline \multicolumn{2}{|l|}{$\mathrm{r}$} & \multicolumn{3}{|l|}{$6.37[34]$} \\
\hline \multicolumn{2}{|l|}{$\mathrm{TF}$} & $1[27]$ & \multicolumn{2}{|l|}{0.9711 [27] } \\
\hline \multicolumn{2}{|l|}{$\mathrm{PF}$} & 0.677 & 0.608 & 0.987 \\
\hline \multicolumn{2}{|l|}{$\mathrm{d}$} & $0.6[16,27]$ & \multicolumn{2}{|l|}{$0.2[16,27]$} \\
\hline \multirow[b]{2}{*}{$\mathrm{r}$} & Blue Map & $\begin{array}{c}0.102 \\
{[16,27]}\end{array}$ & \multicolumn{2}{|l|}{$0.32[16,27]$} \\
\hline & Road Map & $\begin{array}{c}0.185 \\
{[16,27]}\end{array}$ & \multicolumn{2}{|c|}{ 2nd grade polynomial } \\
\hline
\end{tabular}

TABLE V: VALUES FOR THE LCOE SIMULATION

All in all, two main steps of calculations are committed. Firstly, the calculation of annual energy output of all corresponding plants, which is simulated with System Advisor Model. The results will then provide relevant data to calculate the LCOE projection of all plants based on the mathematical model, which is simulated throughout the years until 2030 on the further step.

\section{RESULTS AND DISCUSSION}

The simulated annual energy output of those plant designs using System Advisor Model can be observed in Fig. 2. The result shows that the solar thermal power plant with no storage produces the least amount of annual energy, which is 14.43
GWh, due to its low capacity factor. On the other hand, the solar thermal power plant with 6-hour storage design is able to produce slightly higher annual output (23.432 GWh) compared to the PV plant (22.934 GWh) in Rongkop.

However, aside of the annual energy output calculation, in this paper the comparative assessment mainly lies in calculating the annual levelized cost of electricity of all the plant designs in Rongkop, Gunungkidul until year 2030; as to measure the economic competitiveness of the thermal plants in comparison to the more widely-implemented PV plant.

Fig. 3 shows the comparison of LCOE between the solar thermal plant with no storage, the 6-hour-storage-equipped solar thermal plant and the PV plant in the Blue Map projection. And Fig. 4 shows the comparison of LCOE between the solar thermal plant with no storage, the 6-hour-storage-equipped solar thermal plant and the PV plant in the Road Map projection.

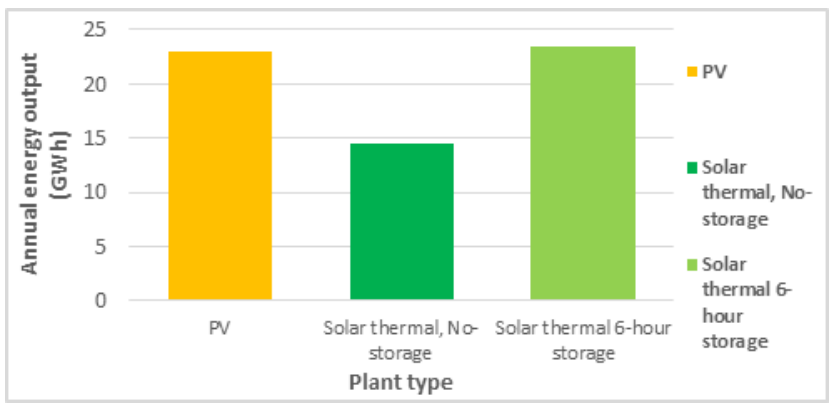

Fig. 2. Simulated annual energy output of solar plants.

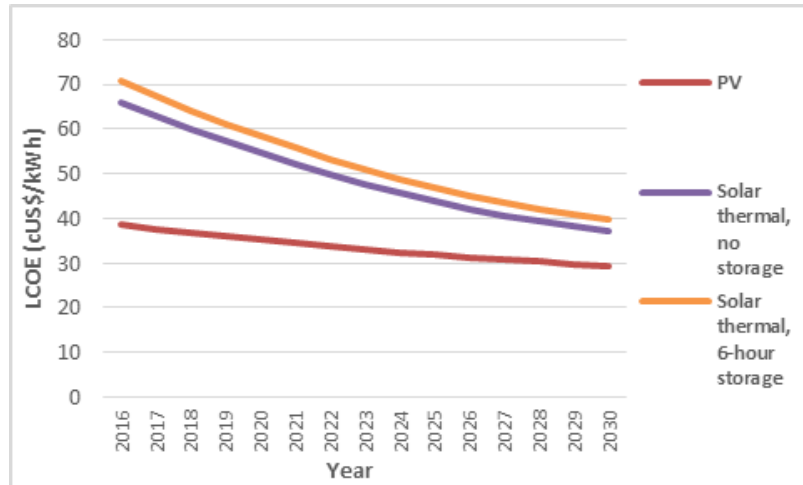

Fig. 3. LCOE comparison of PV and solar thermal plant in Blue Map scenario.

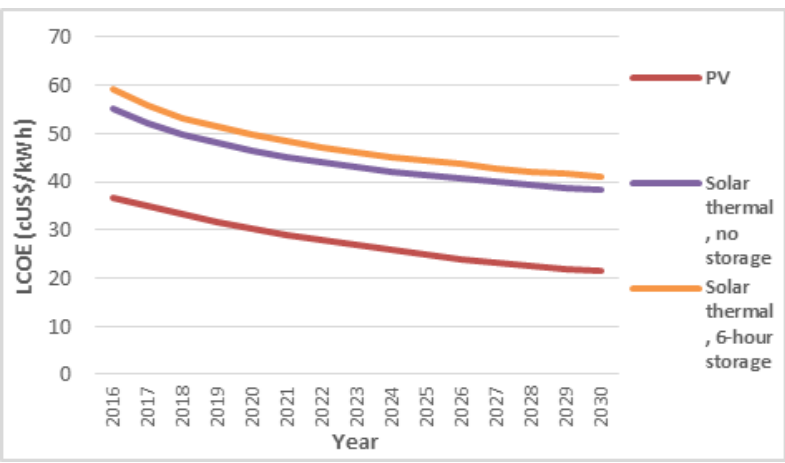

Fig. 4. LCOE comparison of PV and solar thermal plant in Road Map scenario.

According to both figures, the LCOE values of all power plants decrease over the years of simulation. The high projection of installed PV capacity in the Road Map scenario leads to a more significant decrease of the LCOE of PV plants, 
compared to the Blue Map scenario. On the other hand, until year 2027 the Road Map projection gives the lower LCOE values of solar thermal plants than the ones in the Blue Map. Also, the results show that in Rongkop, Indonesia, the LCOE values of solar thermal with 6-hour storage are higher than the no-storage solar thermal plant throughout the years of simulation.

Comparing the LCOE of PV and solar thermal plant in Rongkop through the graphs, it clearly shows that throughout the years of simulation until 2030 the LCOE values of PV plants remain significantly lower than the ones of solar thermal plant. Then, regarding solar power plant implementation in Rongkop, this result implies the dominance of PV in terms of economic competitiveness compared to the solar thermal plant until 2030, the SDGs target year.

\section{SUMMARY}

Inevitably, the renewable energy policy realized in the national level in Indonesia should also be supported by the similar commitment by the local governments as well. The recently proposed Rongkop district in Gunungkidul, Indonesia as the solar power plant center may display the commitment from the government of Yogyakarta province to develop its renewable energy potential. The room for solar power technology implementation there is large given large area of land prepared. Accordingly, this paper may work as a preliminary economic assessment regarding the comparison between two solar power plant technologies: the photovoltaic (PV) and solar thermal, until year 2030.

The result of this research shows that despite the slightly higher annual energy output of the 6-hour storage-equipped solar thermal plant compared to the PV plant, the economic competitiveness of PV plant far exceeds the solar thermal plant designs; be it the one with no storage and also the one with 6-hour storage. Correspondingly, the whole result of this simulation is expected to be an input for the respected policymakers and investors regarding solar power plant implementation in Rongkop district, Indonesia.

\section{ACKNOWLEDGMENT}

This research is financially supported by Indonesia Endowment Fund for Education (LPDP), The Ministry of Finance of the Republic of Indonesia. The author would like to thank Eddy Haryanto, Tan Suzy, and Yoana Wida Kristiawati for their heartfelt support during the completion process of this paper.

\section{REFERENCES}

[1] National Energy Council. 2014 Indonesia Energy Outlook. December $2014 . \quad$ [Online]. Available: http://prokum.esdm.go.id/Publikasi/Outlook\%20Energi\%202014.pdf

[2] J. G. J. Olivier et al., Trends in Global CO2 Emissions - 2015 Report. The Hague: PBL Netherlands Environmental Assessment Agency; Ispra: European Commission, Joint Research Centre, 2015.

[3] United Nations, Transforming Our World: The 2030 Agenda for Sustainable Development, October 2015.

[4] Ministry of Energy and Natural Resources of Indonesia, Perkembangan Penyediaan dan Pemanfaatan Migas, Batubara, Energi Terbarukan, dan Listrik, December 2015.

[5] Ministry of Energy and Natural Resources of Indonesia, PerMen 19/2016: Pembelian Tenaga Listrik Dari Pembangkit Listrik Tenaga
Surya Fotovoltaik oleh PT Perusahaan Listrik Negara (Persero). July 2016.

[6] Tempo. Yogyakarta Prepares Land for Solar Power Center. [Online]. Available:

http://en.tempo.co/read/news/2016/02/12/056744391/Yogyakarta-Pre pares-Land-for-Solar-Power-Center

[7] GeoEnergi. Medco Akan Bangun PLTS di Yogyakarta. [Online] Available:

http://geoenergi.co.id/2016/02/medco-akan-bangun-plts-di-yogyakart a/

[8] BPS - Statistics of Gunungkidul Regency, Rongkop Regency in Figures, 2013.

[9] H. Indrawan, A. Yogianto et al. Kajian Pembangkit Listrik Tenaga Solar Thermal dengan Metode Parabolic Trough. [Online]. Available: http://www.pln.co.id/puslitbang/?p=570

[10] G. Pikra, A. J. Purwanto, and A. Santoso, "Effect of regenerative organic Rankine cycle (RORC) on the performance of solar thermal power plant in Yogyakarta, Indonesia," Journal of Mechatronics, Electrical Power, and Vehicular Technology, vol. 4, pp. 25-32. July 2013.

[11] G. Pikra et al., "Development of small scale concentrated solar power plant using organic Rankine cycle for isolated region in Indonesia," Energy Procedia, vol. 32, pp. 122-128, 2013.

[12] International Energy Agency (IEA), Technology Roadmap - Solar Photovoltaic Energy, Paris, France: Inernational Energy Agency, IEA/OECD, 2010.

[13] M. Buresch, Photovoltaic Energy Systems: Design and Installation, USA: McGraw-Hill, Inc., 1983.

[14] International Renewable Energy Agency (IRENA), Renewable Energy Technologies: Cost Analysis Series - Solar Photovoltaics, vol. 1, issue 4/5, 2012.

[15] H. Winkler, A. Hughes, and M. Haw, "Technology learning for renewable energy: Implications for South Africa's long-term mitigation scenarios," Energy Policy, vol. 37, issue 11, pp. 4987-4996, November 2009

[16] C. Parrado, A. Girard, F. Simon, E. L. F. Vidal, "2050 LCOE (Levelized Cost of Energy) projection for a hybrid PV (photovoltaic) CSP (concentrated solar power) plant in the Atacama Desert, Chile," Energy, vol. 94, pp. 422-430, January 2016.

[17] S. Vergura and V. Lameira, "Technical-financial comparison between a PV plant and a CSP plant," Revista Electronical Sistemas \& Gestao, vol. 6, pp. 210-220, 2011.

[18] International Energy Agency (IEA), Energy Technology Perspectives 2008: Scenarios and Strategies to 2050, Paris, France: International Energy Agency, IEA/OECD, 2008.

[19] REN21, Renewables 2015 Global Status Report, Paris: REN21 Secretariat, 2015.

[20] A. Barua, "Analysis of concentrated solar power technologies' feasibility, selection, and promotional strategy for Bangladesh," Journal of Mechanical Engineering, vol. ME 44, no. 2, December 2014.

[21] International Energy Agency (IEA). Technology Roadmap - Solar Thermal Electricity, Paris, France: International Energy Agency, 2014

[22] P. Denholm and M. Hummon, Simulating the Value of Concentrating Solar Power with Thermal Energy Storage in a Production Cost Model, National Renewable Energy Laboratory, NREL/TP-6A20-56731, November 2012.

[23] C. Turchi, M. Mehos, C. K. Ho, and G. J. Kolb, "Current and future costs for parabolic trough and power tower systems in the US market," Presented at Solar PACES 2010, Perpignan, France, September 21-24, 2010.

[24] CSP World. Andasol 1. [Online]. Available: http://www.cspworld.org/cspworldmap/andasol-1

[25] E. Juanda. "Economic and performance analysis of crystalline and thin film photovoltaic system using system advisor model (SAM) in Four different islands in Indonesia," Thesis, Department of Electrical Engineering, Universitas Indonesia, 2016.

[26] K. Branker, M. J. M. Pathak, J. M. Pearce, "A review of solar photovoltaic levelized cost of electricity," Renewable and Sustainable Energy Reviews, vol. 15, issue 9, pp. 4470-4482, December 2011.

[27] J. Hernandez-Moro and J. M. Martinez-Duart, "Analytical model for solar PV and CSP electricity costs: present LCOE values and their future evolution," Renewable and Sustainable Energy Reviews, vol. 20, pp. 119-132, April 2013.

[28] United States Energy Information Administration. Levelized Cost and Levelized Avoided Cost of New Generation Resources in the Annual Energy Outlook 2016. (August 2016). [Online]. Available: https://www.eia.gov/forecasts/aeo/pdf/electricity_generation.pdf 
[29] International Energy Agency and Nuclear Energy Agency, Projected Costs of Generating Electricity 2010 Edition, Organization for Economic Cooperation \& Development, France, 2010.

[30] G. F. Nemet, "Beyond the learning curve: Factors influencing cost reductions in Photovoltaics," Energy Policy, vol. 34, issue 17, pp. 3218-3232, November 2006.

[31] R. Bhandari and I. Stadler, "Grid parity analysis of solar photovoltaic systems in Germany using experience curves," Solar Energy, vol. 83, issue 9, pp. 1634-1644, September 2009.

[32] H. Winkler, A. Hughes, and M. Haw, "Technology learning for renewable energy: Implications for South Africa's long-term mitigation scenarios," Energy Policy, vol. 37, issue 11, pp. 4987-4996, November 2009.

[33] International Electrotechnical Commission. Efficient Electrical Energy Transmission and Distribution. 2007. [Online]. Available: http://www.iec.ch/about/brochures/pdf/technology/transmission.pdf
[34] Central Intelligence Agency. The World Factbook: Country Comparison - Central Bank Discount Rate.

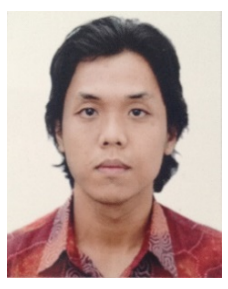

Rizky Januar was born in Jakarta, on January 16, 1991. He earned his bachelor degree in electical engineering from Gadjah Mada University in 2013 focusing on electrical power system. He graduated with an undergraduate thesis on solar energy technology simulation and feasibility study.

After graduation, he worked in education and community development field for a year with Indonesia Teaches Movement. Then, he joined the innovation and competitiveness policy advising team at the Ministry of Education and Culture of Indonesia. Currently, he is pursuing masters degree in Engineering and Policy Analysis programme at TU Delft, Netherlands. 